\title{
Frankenheimer on Location in Canada
}

\author{
By Gerald Pratley
}

Fall 1999 Issue of KINEMA

THE DISTINGUISHED American filmmaker, John Frankenheimer, has returned to Canada and is making his fourth motion picture there called Reindeer Games presently filming in Vancouver, British Columbia, for Miramax. The main players are Gary Sinese, Charlize Theron, Ben Affleck and Clarence Williams III. Frankenheimer is working from a script by Ehren Kruger, the writer's second screenplay following Arlington Way, released this summer.

Frankenheimer first came to British Columbia twenty years ago to film Prophecy, a horror story rooted in the pollution of the environment by the logging industries. He returned ten years later to Calgary, Drumheller and High River, to film Dead Bang, a brilliant piece of work based on the true story of a vicious white supremacy movement. He was back a year later, to Bragg Creek, Canmore and Calgary, to make The Fourth War, set on the snowbound Czech-West German frontier during the Cold War and relating a thoughtful moral tale of two generals, one American the other Russian, and their conflicting ideological beliefs.

Now he is snowbound once again high in the Cypress Bowl mountains of West Vancouver shooting all-night scenes in freezing-cold weather with the unit bathed in the eerie light of Musko location lamps raised high in the dark sky. Affleck plays a newly released prisoner who assumes another man's identity and finds himself involved in a casino robbery at Christmas time. The script appealed to Frankenheimer as a thoughtfully written story concerning men who were born evil and have become a violent sore to plague a complaisant society. His reasons for filming in Canada are not motivated by the money saved due to the favourable exchange rate (although this is not to be discounted!) but because Vancouver, in this instance, is the only place in North America with snow at this time of the year backed by considerable technical and acting resources (of the BC film industry) which are essential in making possible a $\$$ US50m production such as this.

Frankenheimer holds a unique place in American film history This is his 35th film in his forty years in Hollywood, first in the pioneer days of truly 'live' television, and then in feature films. He is one of the very few remaining directors who came to prominence in tv and moved into film (Sidney Lumet, Delbert Mann, Sydney Pollack, the late Franklin Schaffner, to name a few) who is still working steadily moving easily between feature and television films (The Year of the Gun, Against the Wall, The Burning Season, Andersonville, George Wallace, Ronin) all of which are motion pictures in their purest sense. While Spielberg and Lucas are better known, neither of them come anywhere near Frankenheimer's skill with cameras, screenplays, in editing and with an unfailing understanding of actors. And although he has never become a darling of certain critics (he wouldn't want to be) such as Scorsese, Coppola, Altman, Lynch and the wretched Tarantino, his quiet and humane work place him among the great directors of our time. Over six feet tall, thin and weatherbeaten from years of difficult location shooting, and seemingly possessed of a steady flow of energy and a never failing source of inspiration driving his working methods and their creative results.

Intense, brooding, serious and thoughtful, yet not lacking a warm sense of humour, Frankenheimer has never made his name at the expense of shouting publicly at Hollywood over the way he and his films may or may not have been treated. He is well aware of the film city's shortcomings, its liars and the cheats; but he also recognizes the many honest individuals who do their best to live up to their promises, to keep their word and maintain their support during difficult days of production. For this he is highly respected among the ranks of those who run the studios. He has never "gone public" to critics and the media about behind the scenes disagreements. He has fought many battles over the years, lost some, but won most of them, and he has continued a steady output of memorable films, including The Birdman of Alcatraz, All Fall Down, The Fixer, Black Sunday, I Walk the Line, and the unforgettable Seconds. And proud although he is of The Manchurian Candidate it irks him at times when many critics limited in their knowledge and perception are so shortsighted that every time they review one of his films they always look back to this picture and compare it to his latest as though he had done nothing worth mentioning in the years between.

Still, it gives him a continuing satisfaction in knowing that The Manchurian Candidate remains as muchmentioned today as Welles' Citizen Kane and few other films come to mind as easily as the Candidate. 
Incidentally, the rumours going around that it will be remade should not be taken seriously. When asked about this the director will say, for the umpteenth time, that "Mrs. Sinatra has talked about this remake for several years but it has come to nothing." And he hopes it won't. He doesn't think it's a good idea at all, not because of any professional jealously but because it is film of its time and it simply would not work today. And of course, it was so perfectly made with the most perfect cast of players that it would be ridiculous to even try! (On the other hand, his Seven Days in May was remade for tv as The Enemy Within. It was nowhere as good as the original, but remained a contemporary subject bearing in mind the continuing peremptoriness of the Pentagon.)

In every picture he has made his narratives are clearly told, but not without imagination, style and variations, and never lacking in different layers of meaning. The ambiguities relating to human nature, contrary and inexplicable at times, accompanied by subtle interpretations of characters and their motivations, are ever present conveyed through expressive actions and refined direction. His film previous to Reindeer Games, the well received and popular Ronin, is a good example of this, in which characters are puzzling and mystifying at times, but not because the director didn't know them or failed to make them come truthfully to life.

He has never been a media or a party person. He lives quietly with his actress wife, Evans Evans, in a pleasant Beverly Hills home. They travel together, she is always on location with him, and between films they watch the passing Hollywood parade. Although "belonging" to Hollywood they remain detached from trade controversies, the activists' protests, industry power politics, and the not-so-private scandals laid bare in tv interviews in which popular players of the day, who may be effective in front of the cameras, become idiots in the comfort of the interviewers' chairs. For Frankenheimer, making movies is his life's work; with one finished, he is anxious to start another. What he has to say about social issues and their political ramifications is in his films. He is not ashamed to admit he is a "director for hire" but not to take on anything which happens to come along. He looks for stories he can relate to and understand, which are significant in the way society behaves today, whose characters have depth, and decency, who suffer and sometimes triumph. The number of awful scripts sent to him he finds depressing, but even more so are the number of them which get made! But he does not make hay at anyone's expense in the world of filmmaking. He enjoys going away on location, to create other worlds and other lives, which he does flawlessly, persuasively with compelling results.

He is particularly proud of Ronin and likes to discuss it. It is one a.m. and filming stops on Reindeer Games for dinner. The bundled-up crew shuffle through ice and snow and along cleared pathways to the immense trailer dispensing a variety of good, hot food -- with all the various special diets expected by the faddists. Large tents with giant heaters blasting away provide shelter as the talkative and cheerful member of the unit sit at long tables on worn chairs eating, talking, gossiping, laughing and recalling other films at other places; they are friendly individuals but their world is a fairly closed one, and their conversations are those an outsider is not privileged to know. The principals are American and British, the supporting members are efficient Vancouverites working in Canada's largest "American production centre." When Frankenheimer was filming Andersonville in Georgia the prison setting was thick with mud and his trailer was a mess of muddied everything. Here in the mountains it is a clean impressive home-from-home where much of the daily details of filming are discussed with unit members responsible for carrying out the director's instructions.

One of his most valuable associates who entered is Canadian stedicam operator, David Crone, who is working on his fifth film with Frankenheimer and was almost killed while photographing one of the many car crashes in Ronin. The director is without doubt far ahead of all others when it comes to using the stedicam creatively. In a Frankenheimer film, there is none of the stomach-turning whirling around in maddeningly camera movements. Rather, the stedicam is used with such skill and imagination that one can hardly tell the difference between it and the regular camera -- especially while they are moving. Knowing exactly where to place and use the camera, no matter what the scene, makes the difference between a great and an ordinary filmmaker -- but is hard to achieve without an operator as adept and understanding as David Crone.

Finally, a break, and Frankenheimer relaxes with a mug of steaming tea. "Ronin came to me in an unexpected way as do many of the scripts I've worked on. I went in to United Artists to see Frank Mancuso Jr. (who is a producer), Lindsay Doron, the President of UA, and Rebecca Pollack, the Vice-President, to talk about The Spider and the Prince, which I was very keen to make. I talked about it and presently I saw the look in their 
eyes and felt immediately that they were not interested in doing this kind of movie. During the discussion they started talking about a film they wanted to make in France, but were running into difficulties because the director they were sending over didn't speak French. I said they were asking for trouble and that I knew from experience what to expect, but being bilingual I didn't have these problems with the films I had made there. I was away over the weekend and when I returned home I found a script awaiting me called Ronin, written by J.D. Zeik, with a letter from my agent saying they didn't want to do The Spider and the Prince but they wanted me to do Ronin."

At this point in our discussion Frankenheimer broke off to speak to his capable assistant, Margo Lane, reminding her to send a copy of the script for The Spider and the Prince to Bob Weinstein in L.A. Continuing, he described his response to Ronin "So I read it and it was finished, more or less, from the script you read, about a group of former espionage agents recruited by an Irish girl to recover a suitcase, the contents of which remain unknown, and taking place in France. I thought the writing lacked maturity and focus but I liked the idea. So I talked to the producers again and said the script needed a lot of work, but I liked the premise, and if they were going to do it we needed to send a location crew to France to find out what it would cost. Before we started to rewrite, the script was sent to various actors who all turned it down.

But then I got a call from Rebecca Pollack who said De Niro was available and did I think he was a good choice for the role of the CIA man? I thought he would be just right for the part and that we were lucky to get him. So De Niro and I sat down with Zeik and I outlined the shortcomings of the script. Zeik said he could address them. Afterwards De Niro called me to ask what I thought of the discussion and I said I didn't think it solved anything and he agreed, saying we should look for another writer. He said, "what do you think of David Mamet and I replied that he would indeed be a very good choice. So that was how he became part of the picture using the pen name of Richard Weisz. I worked out all the action sequences, we kept them all, and re-wrote the dialogue from Page 1. And that's the script we shot in Paris, Nice and Arles. The title has much to say about the subject matter and the idea that these men in Ronin were modern day samurai; yes, that obviously made the story one reason why I wanted to do the movie. It also appealed to me because I know how to film this kind of subject, and the fact that it was set in France and was a big-budget studio film."

The ending however, was changed and Frankenheimer explained why. "We envisioned at the very end that Deirdre would be taken away and one of the captors would say "you know what happens to traitors like you." Deirdre, waiting outside the bar, would be captured by the IRA and shot. After the picture previewed, I decided to change it to the one you see now where Deirdre drives away never to meet Sam again. The entire film emphasizes the right of individuals to be free and self-determining agents. Unlike the "Ronin" of old who had nowhere to turn once their masters were gone, their present day equivalents, who worked under cover for their countries during the cold war are yes, master spies who continue to seek out and defend right against wrong, good against evil, thoughtful men who, at times, were even given to meditation."

This treatment of the story gives the director the opportunity to avoid time spent on exposition, the giving of reasons through account or commentary, which he highly dislikes directing. He believes that explanations about the behaviour and background of the people in his stories come best largely from their activities interlaced with sufficient dialogue filling in reason and purpose. We are held too, under the spell of what was in the case, the Hitchcockian McGuffin element, which was also the red herring. "Forget the case, I was never after the case. I was after him." De Niro's mission was to get the IRA terrorist, played with consummate artistry by Jonathan Pryce. And as for De Niro, it seems he never left the CIA:. Did he mean in fact or in his belief that he would always be part of the organization because without it he would have no reason to live?

"Ronin is an existential film." says the director. "People don't go into self-explanatory speeches or give long reasons as to why they do certain things and where they came from, which I like. You know, as soon as Sam (De Niro) appears, who he is; you see him walk into the bar. This is a long, visual sequence -- there are few words -- but you understand. The film is like this until the end. You see other characters come into the bar. Something is going on. Sam is not an ordinary tourist. And you know he is fluent in French. "I never want to go into a place I cannot get out of..." This begins the story. I'm very pleased with that scene in the bar. The steps outside were real, the bar interior was a studio set. I simply do not like long expositional 
scenes with characters telling us who they are. I do everything I can to avoid directing them. I hate looking at them in other films. I love the scene with Sam in the car with Deirdre. To hide from the passing crooks they embrace to cover their faces. When they have passed, Sam and Deirdre part, look at each other and embrace again, when a police car passes. This time it is with an expression of tender affection turning into feelings of passion. There's hardly a word spoken, but the exposition is there. She says, more-or-less, 'my life? seduced and abandoned,' and again, we sense what kind of a world she has lived in."

Ronin is also a self-reflexive film meaning that the director has knowingly and with more than a hint of humour borrowed from himself by bringing in scenes which acknowledge their presence in other Frankenheimer films, the most prominent being the stadium finale from The Manchurian Candidate -- and still a thrilling moment. Television screens and monitors, mirrors and shadows, a Frankenheimer hallmark, are there, and a witty mention of Doctor Zhivago by David Lean, a director whose films Frankenheimer greatly admires. Another example of course are the races of Grand Prix seen in Ronin as high-speed chases through the streets of Paris. They are so brilliantly done and so exciting throughout that the director finds himself questioned by almost everyone asking "how did you do this?" Frankenheimer replies, "Well, I spent hours recently recording commentaries about this for the DVD disc giving viewers an almost complete account of how we worked out the car sequences. First we sent out the art director -- or production designer as they call them now -- with a group of experts to determine where we would stage all this. Everything was pre-planned. We sketched them, with Ted Boonthanakit, as story boards; we put cameras in crash boxes, on cars and in cars, took shots of actors in and out of cars, towed cut-up cars, we used right-hand versions of the cars from England for close-ups of the actors who appeared to be driving but the actual driver was out of the shot driving on the right-hand side of the cars. We drove at the speeds you see in the picture and there were no special effects. Every car coming and going, passing or swerving, was driven by an expert racing driver. We had 300 French drivers at the wheels of all other cars on the road and for help in all this I have to thank Jean Claude Lagniez. There were all manner of ways and techniques we used, cameras with different lenses, and every move for every car was worked out in advance. It was very exciting, it was terribly dangerous, lives were often in jeopardy and it took a great many weeks -- and then I did 28 days on second unit filming; all the roads were blocked off to traffic, we controlled everything we shot and the French police were extremely helpful. And it all came together in the editing process with Tony Gibbs, one of the best editors still working today."

The bars, cafes, houses, and other interiors have the look, and create the atmosphere, of classic French films from past eras. This, said Frankenheimer, was what he set out to achieve, adding with a laugh, "I think I now have 'my trilogy' (a reference to the works of other directors, among them Bergman, Satyajit Ray, Kobayashi, Donski) with The Train, French Connection II and Ronin, which have several traits in common: a graphic French realism and characterization, pervaded with tragedy and humour." (The director has made two other films in France: Grand Prix (in part) and the little-known but memorable, Impossible Object.)

And what did all of this cost? For Frankenheimer, never known to be an "over-budget" filmmaker and who has achieved remarkable results on low budgets, Ronin was his most expensive film at \$US54m. "Well," he said with a touch of humour, "I didn't waste money. We live in inflationary times, it's expensive shooting in France and the money is all there up on the screen. The studio got its moneysworth, car chases do not come cheap, and De Niro doesn't work for scale!

"I'm not lightning fast, but I'm not slow either. I tend to shoot a lot of set-ups. I was an editor and director in live television, that's what I did, and I watched every shot on the screen -- in rehearsal and in performance. I knew what was needed in editing and I still do. I shoot a lot of coverage, and making Ronin was an experience I enjoyed immensely."

He did not however, feel this way about The Island of Doctor Moreau. There was a long pause before he replied: "Looking back, I'll say this; there are a few aspects to the movie I liked; I think Brando's performance was quite extraordinary, the interplay of the animals was good and David Thewlis was very, very good and Fairuza Balk gave a performance of depth and feeling. I think if the movie failed it was because of Val Kilmer, who refused to do scenes that were essential to make the film work and because of the terrible negative affect he had on the entire production. He was just despicable and not only because of what he does to people but what he did to the movie. It could have been a brilliant picture had it not been for Kilmer, but he 
ruined everything that everybody was trying to do. There was a time when we had no script because Kilmer refused the script we wanted to do, and I had to bring screenwriter Ron Hutchinson over to re-write. At one point we looked at each other, because the studio didn't support us, and we said "who's going to take over the island?" this being a very expensive movie to do, so far away in Australia.

The budget was $\$$ US50m and money was going down the drain every day, wasted, and I hate to see that. To give you just one example, for a difficult scene between Kilmer and Brando, the camera was ready to shoot, the crew was in position, the two actors knew what the shot was and everyone waited -- for 12 days, think of that, for 12 days at 150,000 dollars a day. That's close to two million dollars that might as well have been used for toilet paper, all because of Kilmer and Brando not showing up or spending time on endless meetings about nothing. Edward Pressman, the producer, was never there; there is no comparison between him and Frank Mancuso Jr. or Marty Katz, the producer on Reindeer Games, who really help you. However, if you go through a soul searching experience as I did on The Island of Doctor Moreau where you come out of it intact, I honestly feel that living through that experience with Kilmer has made me a much stronger person. That was as bad as it could possibly get. Having survived has given me tremendous courage because nobody can give me anything that's going to be more difficult."

In closing his conversation, Frankenheimer feels that "My years in film have meant a constant trying for perfection. You are never going to do the ideal sequence, never; never going to make the perfect film. Many times you look at a sequence and you say, well, it didn't work as well as I hoped it would, but then there are a few times, very few, when it might work better than you imagined it would. It's mainly a process of not being able to realize what you ideally want, but you keep on trying and that's why I keep on going, because I hope some day to make the film that's in my head when I start. But I've never been able to do it. My being in Canada again is a miracle, but my life has been a kind of miracle and I'm very pleased to have come back here under the best conditions possible in my life today."

(Ronin is available for rent on videocassette and for purchase on DVD.)

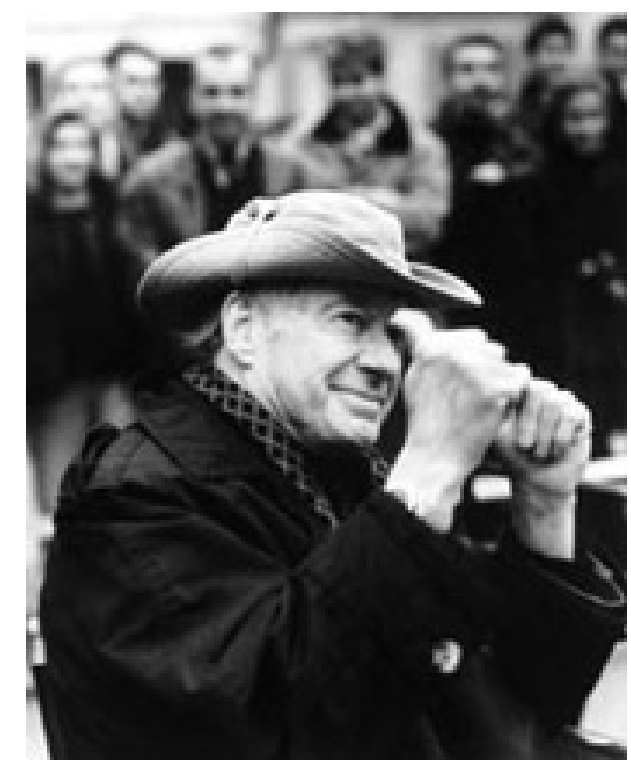

Figure 1: Director John Frankenheimer

\section{Author Information}

Gerald PRATLEY, OC, LLD, started his career as film critic with the CBC. In 1969, he founded the Ontario Film Institute which he directed until 1990. He has written several books and numerous articles on film, 
including Torn Sprockets, a history of Canadian cinema. He taught Film History in universities in Toronto and Waterloo, Canada and holds three honorary degrees from Canadian and US universities.

Gerald A. Pratley (1923-2011) was born and educated in London, England, and came to Canada in 1946. He started working in Toronto for the $\mathrm{CBC}$ as a scriptwriter. He was drawn toward working in motion pictures, and became, in 1948, the CBC's first film critic and commentator.

Gerald Pratley broadcast three programmes a week, Pratley at the Movies, The Movie Scene, Music From the Films, and others, until 1975. During this time he also became the first post-war chairman of the Toronto Film Society, chairman of the Toronto and District Film Council and co-founder of the A-G-E Film Society and correspondent for international magazines such as Films and Filming, Film In Review, Variety, Hollywood Quarterly and International Film Guide. During the 1950s he wrote for Canadian Film Weekly and Canadian Film Digest.

He became known as a speaker on all aspects of motion picture art and industry, and was invited to teach film history at the University of Toronto, York University, University of Waterloo, Seneca College and Ryerson Polytechnical University, with individual lectures being given at many other Canadian and US universities and colleges. He has served as a member of various judging panels of competitions and festivals, being one of the members of the first Canadian Film Awards in 1949.

From 1970 to 1975 he was the director of the Stratford (Ontario) International Film Festival, and from 1969 to 1976 he was Chairman of the International Jury of the Canadian Film Awards. He has attended all the world's leading festivals of film, and in particular, for 30 years, the Cannes Festival as CBC correspondent. He has written six books, The Films of Frankenheimer: Forty Years in Film; The Cinema of John Frankenheimer; The Cinema of Otto Preminger; The Cinema of David Lean; The Cinema of John Huston, and Torn Sprockets, a history of the Canadian cinema.

Gerald Pratley has served on the Advisory Boards of the film departments of Ryerson Polytechnical University and Humber College, and as a member of the programme committee of TV Ontario. In 1968 he became the founder-director of the Ontario Film Institute of the Province of Ontario, an organization which has distinguished itself in archival holdings and public service and is known since 1990 as the Cinematheque of Ontario. He taught Film History courses at the Department of Film and Photography, Ryerson Polytechnic University, Toronto and the University of Waterloo.

In 1984, Gerald Pratley was made a Member of the Order of Canada and in 2003 Officer of the Order of Canada for his service to Canada through film appreciation. He holds Honorary Degrees in Letters and Fine Arts from York and Waterloo Universities (Ont., Canada) and Bowling Green State University (Ohio, USA).

In 2002, Gerald Pratley received a Special Genie Award from the Academy of Canadian Cinema \& Television in recognition of his lifelong dedication to the promotion and his exceptional support of Canadian cinema.

He died on 14 March 2011 in Ontario, Canada. 